\title{
ATUALIZAÇÃO BASEADA EM EVIDÊNCIAS E CENTRADA NO PACIENTE
}

\begin{abstract}
Wanderley M. Bernardo, Moacyr C. Nobre
Esta seção da RAMB tem como objetivo principal trazer ao leitor, especialista ou generalista, casos clínicos da prática diária, para que sejam discutidos à luz das recomendações do Projeto Diretrizes da AMB e CFM.

Em cada edição da Revista, um especialista convidado, participante na elaboração de diretrizes baseadas em evidências, apresentará um caso clínico, associado a uma série de perguntas, cujas respostas podem ser obtidas na Diretriz AMB-CFM correspondente ao tema abordado. As diretrizes podem ser consultadas nos endereços eletrônicos: www.projetodiretrizes. org.br ou www.amb.org.br, e as respostas às questões clínicas serão disponibilizadas nesta seção, na edição subseqüente.

Faz parte do projeto da RAMB, disponibilizar esta seção on-line, em planilha apropriada, para que o leitor possa participar, por meio de suas respostas, de processo educativo continuado, que poderá somar pontos para o certificado de atualização profissional.

Esperamos que cenários clínicos abordando dúvidas em diagnóstico, terapêutica, prognóstico, etiologia ou ética, discutidos frente às recomendações do Projeto Diretrizes, possam contribuir para a disseminação do conhecimento baseado em evidências e centrado no paciente, como também para a atualização e auto-avaliação médica.
\end{abstract}

\section{TEMA ABORDADO}

Especialidades de abrangência: Reumatologia, Clínica Médica, Hematologia, Cardiologia, Psiquiatria, Pneumologia, Nefrologia, Ginecologia e Obstetrícia.

Diretriz a ser consultada: $\quad$ Tratamento do acometimento sistêmico do Lupus Eritematoso.

\section{Cenários e questóes clínicas}

Paciente do sexo feminino, de 38 anos de idade, procura médico, com queixa de cansaço a médios esforços e inchaço nas pernas. Ao ser examinada, notou-se redução da ausculta pulmonar em base direita, palidez cutânea mucosa e edema de membros inferiores. Após a internação, os exames revelaram como alterações principais: anemia, teste de coombs positivo, FAN positivo padrão homogêneo, em título alto, anticorpo anti-DNA positivo, leucocitúria e hematúria com dimorfismo eritrocitário, creatinina normal e pequeno derrame pleural à direita. Durante os primeiros dias de internação a paciente apresentou quadro agudo de confusão mental. Em relação a este cenário podemos responder algumas questões:

\section{Em casos com manifestação de anemia hemolítica autoimune, refratários a corticoterapia, qual a opção terapêutica de preferência:}
a) associar azatioprina;
b) utilizar imunoglobulina intravenosa;
c) substituir por outro corticosteróide;
d) associar antimalárico;
e) substituir por ciclofosfamida.

\section{No acometimento cardiopulmonar, beneficia-se da corticoterapia em doses moderadas a seguinte manifestação clínica:}
a) pneumonite aguda;
b) miocardiopatia;
c) pleurite;
d) hemorragia pulmonar;
e) hipertensão pulmonar.

3. Em relação à confusão mental aguda apresentada pela paciente, é verdadeiro afirmar que:

a) não está relacionada às manifestações da doença primária;

b) está obrigatoriamente relacionada à doença de base;

c) a corticoterapia está contra-indicada pois pode agravar o quadro;

d) a ciclofosfamida é opção terapêutica para o acometimento do snc;

e) deve ser tratada com anticonvulsivantes profiláticos.

4. Estão entre as medidas terapêuticas indicadas na nefropatia, exceto:

a) agentes inibidores da angiotensina;

b) glicocorticóide na dose de I a |,5 mg/kg/dia, na glomerulonefrite proliferativa;

c) micofenolato de mofetil na glomerulonefrite proliferativa;

d) a associação de imunossupressor ao corticosteróide mostra melhor resultado na preservação da função renal e na sobrevida;

e) terapia imunossupressora está indicada para casos que já evoluíram para perda da função renal.

5. Se a paciente estivesse em aleitamento, qual a principal mudança no esquema terapêutico ?

a) o uso de azatioprina está contra-indicado;

b) nos casos refratários a predinisona, a ciclosporina não deve ser utilizada;

c) a dose de corticosteróide deve ser inferiores a $20 \mathrm{mg} / \mathrm{dia}$, com intervalo de 4 horas entre a tomada e a amamentação;

d) o controle da atividade da doença deve ser inicialmente com imunoglobulina intravenosa;

e) a presença de anticorpo antifosfolípide contra-indica o uso de aspirina, pelo risco aumentado de sangramento. 


\section{Respostas do Cenário Clínico: “O uso do cinto de segurança durante a gravidez"}

(Publicado na Ver Assoc Med Bras 2005; 5 I (6):3 I 0-I I)

I - Durante a gravidez, os acidentes de trânsito constituem-se na etiologia mais freqüente de mecanismo de trauma; no motivo mais freqüente de hospitalização e na principal causa de óbito fetal relacionada a trauma materno.

2 - Mulheres grávidas que não usam cinto de segurança, quando envolvidas em acidentes de trânsito, podem apresentar maior probabilidade de gerar filhos com baixo-peso ao nascimento e partos 48 horas após o acidente; duas vezes mais hemorragias no parto; 2,8 vezes mais os óbitos fetais e ferimentos severos, traumas abdominais intensos e choque hemorrágico.

3 - Entre os efeitos adversos que acometem as gestantes que não usam o cinto de segurança é a complicação mais freqüente, o descolamento prematuro de placenta.

4 - Em caso de acidente de trânsito envolvendo uma motorista grávida o principal risco para o feto é que a mãe tenha ferimentos ou morra.

5 - A mulher grávida quando motorista ou passageira de um veículo automotor deve posicionar a faixa inferior/pélvica (sub-abdominal) o mais abaixo possível da protuberância abdominal e a faixa diagonal lateralmente ao útero, entre as mamas e no terço médio da clavícula.

6 - Em relação ao airbag na gravidez: seus benefícios superam os riscos, desde que a gestante utilize corretamente o cinto de segurança. 